\title{
STUDENTS' LEARNING STYLE: A CASE STUDY OF SENIOR HIGH SCHOOLS IN BENGKULU
}

\author{
Safnil Arsyad \\ English Education Postgraduate Program \\ Education Faculty of Bengkulu University, Indonesia \\ safnil@unib.ac.id
}

\begin{abstract}
It is widely accepted that the use of learning materials which accommodates students' schemata is much more effective than the ones outside student's present knowledge background. The objectives of this study are to describe the students' learning style distribution and their perception on local oriented and learning style-based English learning materials in Bengkulu Province. The respondents were senior high school students in Bengkulu Province. The results show that : 1) the English learning materials can present a well-designed English learning materials for senior high schools students; 2) the English learning materials with picture stories and visual and audio learning media help students learn English; 3) the learning materials have been designed very well according to the students; 4) as reported by the students the strengths of the English learning materials is that it provides new information on tourism places in Bengkulu Province for the students, 5) the learning materials (the text books and $V C D / C D$ ) could improve their motivation to learn English. It can be concluded that local oriented and learning style-based learning materials can be not only more effective but also preferred by the students.
\end{abstract}

Keywords: perception, local oriented materials, learning style

\section{INTRODUCTION}

The English learning results of junior high-school student in Bengkulu Province viewed from national examination result (NEM) is still far from satisfactory and the improvement from year to year (if available) is not significant. Although the result of National Examination (UN) of English for senior high-school (SMA) level shows a better result, the condition on the field mainly about the senior high-school students who continue their study to university such as to Bengkulu University shows that the English ability is still very weak so that the students cannot use the skill to expand their reading references to read the books or other materials published in English available at the university central library. 


\section{EduLite}

Journal of English Education, Literature, and Culture

The same conclusion is addressed by Priyono (2004) by referring to the research results of various experts in teaching English (e.g. Alisjahbana, 1990; Sadtono, 1983; and Tomlinson, 1990 in Priyono, 2004). Priyono states that more than 90\% of English teachers in Indonesia admitted that the learningteaching processes (PBM) of English could not succeed while the solution during this time was more focused on the method of teaching, the quality and quantity of learning materials available, quality and quantity of media and learning facility available, quality and quantity of English teachers, and quality and quantity of learning activity of English teaching inside and outside the class.

Some high-school and university students in all over Indonesia usually learn English at schools and at non formal English courses in the afternoon or the evening. According to the association of course entrepreneur in Indonesia (HKI), there are at least 25000 courses registered in Indonesia which half of them are English courses (cited in Cahyono and Widiawati, 2002). This number of course is not yet included the English courses in small scales or unregistered ones and the learning activities by inviting private teachers to homes. However the facts show that very few who learns English succeeds to master the foreign language and get benefit out of it such as to get a proper job, to get additional income, to get a higher position, to get scholarship for further study or joining short training in an English speaking country.

Mantiri and Priyono (2004) conclude that although the demand and interest toward the use of English in Indonesia is far more increasing as the result of globalization, the result of learning-teaching processes of English in Indonesia is still far from the achievement target set. According to them, one significant cause of this failure is the quality of teacher which is still questioned; the majority of English teachers are educated with the old teaching styles or inadequately trained, so they lack of capability to adopt the approach of communicative language teaching (CLT). One of the evidences, according to Mantiri and Priyono, is their knowledge and perception about CLT varies one to the other likewise the implementation of CLT in the class. This statement is supported by Dardjowidjojo (1997 and 2000 in Jazadi, 2004) who claims that the majority of English teachers have poor English proficiency. The 
problem is increasingly serious because their incomes are low so they have to seek additional incomes by teaching in various places.

Another influencing factor to the failure of the English teaching in Indonesia is probably the poor quality of English teachers. The majority of English teachers in Indonesia, although graduated from relevant study field, may not be active users of English; the majority of them do not read, listen, write or speak English unless when and about things in the teaching materials of English language within the class and even these are also often delivered in Indonesia or local language. Therefore, the English language skill of the teachers is more and more deteriorating and as the result their self-confidence is also lessening in using English, and they cannot give good example in the use of English for their students.

Although the majority of Indonesian people who learn English fail to achieve the level of success as expected, there is a group of people who are quite successful in mastering the foreign language, so that they have got benefit and profit from it such as getting the proper job, getting the additional income, getting the increase of position, and getting the scholarship to study overseas like: USA, Australia, Canada, England, New Zealand and others. This condition causes a very basic question to appear, i.e.; Why can some Indonesian people be successful in mastering the English language as expected while the majority of them fail?

Various influencing factors towards the success of learning a foreign language such as English have been analysed by the English teaching experts or applied linguists. The factors are: the age to start to learn English language, the contact with English language productively and receptively, the aptitude, the personality, the attitude and motivation, the relation between first language or mother tongue with English language (target language), and others. In addition, those who are successful in learning a language usually have different learning styles but all have typical learning ways which they like; some people, for example, like to learn and at the same time use the language in speaking and writing (productive skills), while many like to learn and at the same time use the language in reading or listening (receptive skills). There are people who learn through grammar and vocabulary, and there are 
people who like to learn directly by using the language both productively (speaking and writing) and receptively (reading and listening). The selection of this method, productive or receptive, will surely influence the mastery of the language skills; but it needs a combination or integration between the two methods since the four language skills (speaking, writing, reading and listening) are equally needed.

There are three types of learning style classified by the language teaching experts, such as Banner and Rainer (2000) and Oxford (2003); these are 'visual', 'auditory' and 'kinaesthetic'. According to them, the students having 'visual' learning style like to learn with media like picture, video, reading and others, the students with 'auditory' learning style like to learn by listening to media such as radio, recorded cassettes, while the students with 'kinaesthetic or tactile' learning style like to learn by moving, doing, touching or playing something.

The importance of student's learning style observed in the English learning process is that if the teaching style of teacher matches the student's learning style, the result of their learning will be better (Banner and Rainer, 2000). With the same tone, Oxford (2003) adds that if the learning style and the learning strategy of students go well with the teaching method and the learning materials used by the teacher the students will be very possible to succeed, have a better self-confidence, and a low 'anxiety'; and on the other hand if there is unsuitability between the learning style and the learning strategy of students with the teaching method and the teaching materials of teacher, the students' learning result will be poor and they will not have selfconfidence and will experience significant anxiety.

Beside the learning style, the additional learning activity outside formal schooling activities will also influence the success of someone in mastering English language. In a survey study toward the lecturers of Bengkulu University who had succeeded in mastering the English language, so they could get a scholarship for studying in an English speaking country, Safnil (1991) found that all lecturers conducted additional learning activities outside their formal classes like reading newspapers, magazines, novels or stories, watching English movies, reading English text-books, listening to the tapes of 
English language, conducting the English tests, writing the diaries in English, speaking to themselves, using the facilities available in the language laboratory or in self-access centre and others.

Extra English learning activities have proven that they could help students very much in mastering a language such as English language. There have been many research findings showing that the learning activities outside the classrooms are far more effective than the learning activities in the formal classes. One of the studies is called 'book flood' study conducted by Elley and Mangubhai (1983). In the research toward the students of senior high-school students in Fiji, Elley and Mangubhai asked the students to read English books which were varied both from the topics and the difficulty levels. The results of their study show that the majority of their students as the research samples who read the reading materials matching their pleasure (reading for pleasure) increased the ability to speak English twice better than the students in the normal class who learned with the help of a teacher. The increasing of speaking ability was not only in the reading skill but also in other skills like listening, structure, vocabulary mastery, and writing.

Another research was conducted by Hafiz and Tudor (1989) toward the children of Pakistan off-springs living in England. Similar to the study by Elley and Mangubhai (1983), the children of Pakistan offspring were equipped with varied and interesting reading materials for them to read outside the formal teaching hour. The results show that the children's English skill improvement was higher than those of the children who were only taught English in formal classes. Hafiz and Tudor concluded that, reading English materials for pleasure could improve significantly the speaking ability of the children, since they got the language input in a larger number and in the difficulty level which matched the level of their English ability. In addition, Bialystok (1978 and 1981) also found out that the forms of leaning activity outside the formal classes improved the English speaking ability of students amongst all, speaking with friends or English speakers, watching English speaking television programs and films, reading various English reading texts, listening to the cassettes of English teaching, and others. 


\section{EduLite}

Journal of English Education, Literature, and Culture

Volume 3, Number 1, February 2018

In his study toward 44 students from various countries in ASEAN like Indonesia, Singapore, Thailand, Malaysia and Philippines who were studying in Australia, Nunan (1991) found that the English learning activity in the class is not enough to master the language, it is very necessary for the students to have additional learning activities both individually and in groups. In other words, the learning activities outside formal and non-formal classes is a must for everyone who learns a foreign language in order to be able to master the language well.

Another important aspect which may affect the success or failure of English teaching and learning activities is the quality of teaching and learning materials. Patel and Jain (2008) state that in order to make English teaching and learning processes effective, teachers must use instructional media and materials and therefore these teaching and learning materials must be in high quality. According to them, among the criteria of good teaching and learning materials and media are that they should accommodate student's differences; the exercises in the textbooks should be practical, the cover and pictures used in the textbook should be attractive and colourful, the topics discussed in the textbooks should be related to the student's interest, and there should be no difficult words and information in the textbook. In addition, Tomlinson (2008) states,

... [learning] materials for learners at all levels must provide exposure to authentic use of English through spoken and written texts with the potential to engage the learners cognitively and affectively. If they don't provide such texts and they don't stimulate the learners to think and feel whilst experiencing them there is very little chance of the materials facilitating any durable language acquisition at all (p:4)

In other words, according to Tomlinson, language teaching and learning materials must be taken from samples of real language use and be able to encourage students to get involve in discussion by using English about the topic presented. In order to meet these criteria, the learning and teaching materials must be the ones that the learners have been familiar with and interested in, so that they have sufficient ideas and opinion to express in the discussion using the language. 
All aspects which may support the success of mastering a foreign language like English language as discussed above can be summarized as in the following figure:

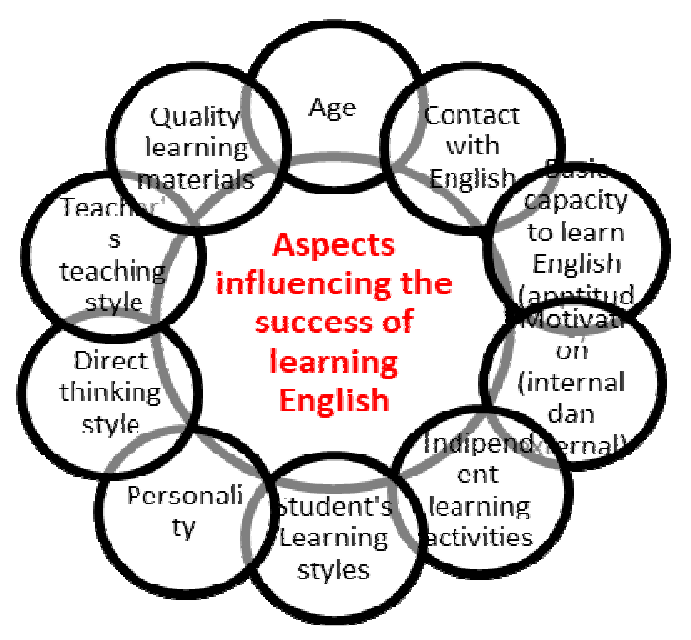

Figure 1: Factors Influencing the Success in Learning

a Foreign Language

As seen in the above figure, many aspects may affect the success or failure in mastering English language; these factors are necessary to be considered by teachers and students of English so that they could successfully master all language skills of English (reading, writing, listening and speaking) at an expected level of proficiency.

In order to help improve the English teaching and learning results at senior high-schools in Bengkulu province, an experimental study has been conducted on the use of local oriented and learning style-based learning materials which were used as supplementary materials. For this study a set of English learning materials were designed based on the characteristics of three different learning styles (visual, auditory and kinaesthetic) as suggested by Banner and Rayner (2000). These English learning materials used local oriented texts which were taken from Bengkulu tourism promotion advertisement in the form texts and videos. The main objective of this study is to see, "How do senior high-school students perceive the English learning materials which have been designed based on three different learning styles 
and local oriented resources? The questions addressed in this research are as follows:

1) How is the learning style of senior high-school students in Bengkulu province?

2) How are English learning materials designed and developed based on local oriented resources and students' learning styles? and

3) How do senior high-school students in Bengkulu province perceive the local oriented and learning style-based English learning materials?

To answer the above questions, a survey on students' learning style was conducted in several senior high-schools in Bengkulu province. Then, supplementary learning materials based on the students' learning styles and local resources were designed and developed. Finally, the learning materials were distributed to students and teachers from sample schools in order to obtain their perception on the supplementary learning materials.

\section{DISCUSSION}

It is necessary to state here again that this research is not to test a hypothesis but to describe whether or not the already designed local oriented and learning style-based English learning materials are found interesting, useful, relevant, and necessary by senior high-school students in Bengkulu Province. The data for this study were taken from senior high-school students and English teachers in six regencies in Bengkulu province: Rejang Lebong, North Bengkulu, Muko-Muko, Lebong, South Bengkulu and Kaur regencies. From each regency in Bengkulu province, only one senior high-school was chosen and from one school only one class was selected and these were done on purpose. Thus, the total number of research samples was 259 senior highschool students. These students were chosen using purposeful sampling technique because it was impossible to choose samples through stratified random and proportional random sampling technique because of limited time and funding. 
The instruments used in this study were two sets of questionnaire: one set of questionnaire for senior high school students to classify their learning style preference and another set to know their perception on the already designed and developed English learning materials. The questionnaire used a closed and open format in which respondents were given optional answers and space to write their additional comments or answers. The participants were given a set of English learning materials which matched their learning style beforehand (a textbook and a CD, VCD or a game) and then they were asked to fill in the questionnaire.

The supplementary learning materials used in this study were designed based on three different learning styles: visual, auditory and kinaesthetic. The main difference between three kinds of English learning materials is on the learning tasks assigned for the students. As discussed earlier in this article, visual learners prefer learning by reading or watching; auditory learners like learning by listening; and kinaesthetic learners learn by doing, touching or manipulating objects, or by using their hands. Following this principle, every after reading and/or listening activity in the learning materials, the students with different learning styles are assigned to do different set of follow-up activities; however the English reading or listening texts are the same for the three different learning styles; these are the ones taken from tourism information available in Bengkulu province.

Among the learning activities assigned for students with visual learning styles are a) information transfer activities, b) true-false reading comprehension, c) close procedure, d) matching vocabulary exercises, e) describing pictures for writing activities, f) diagram completion activity, g) speaking demonstration activity. The learning activities for the students with auditory learning styles are a) reading aloud activity, b) oral discussion, c) listening to $\mathrm{CD}, \mathrm{d}$ ) repeating texts activity, e) following verbal direction, and $\mathrm{f}$ listening to pictures activity. The learning activities for the learners with kinaesthetic learning styles are a) note taking from listening activity, b) tracing words with student's finger for reading activity, c) role play activity, d) acting out activity, and e) playing games. 
The first result of this study is the distribution of student's learning style within three different styles: visual, auditory and kinaesthetic styles. The distribution is given in Figure 2 below.

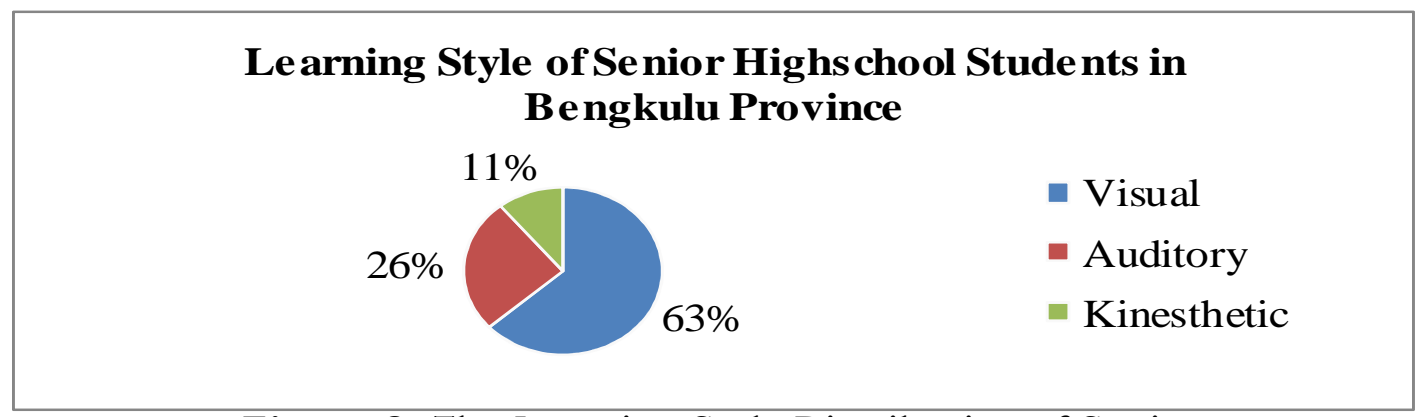

Figure 2: The Learning Style Distribution of Senior High-school Students

As can be seen in the above figure, the data show that the majority of the students are classified into having visual learning style (164 or $63,3 \%)$ and 67 students $(25,9 \%)$ have auditory learning style and only 28 (10,8\%) have kinaesthetic learning style. In addition, the distribution of the students' learning style from each regency can be seen in Figure 3 below.

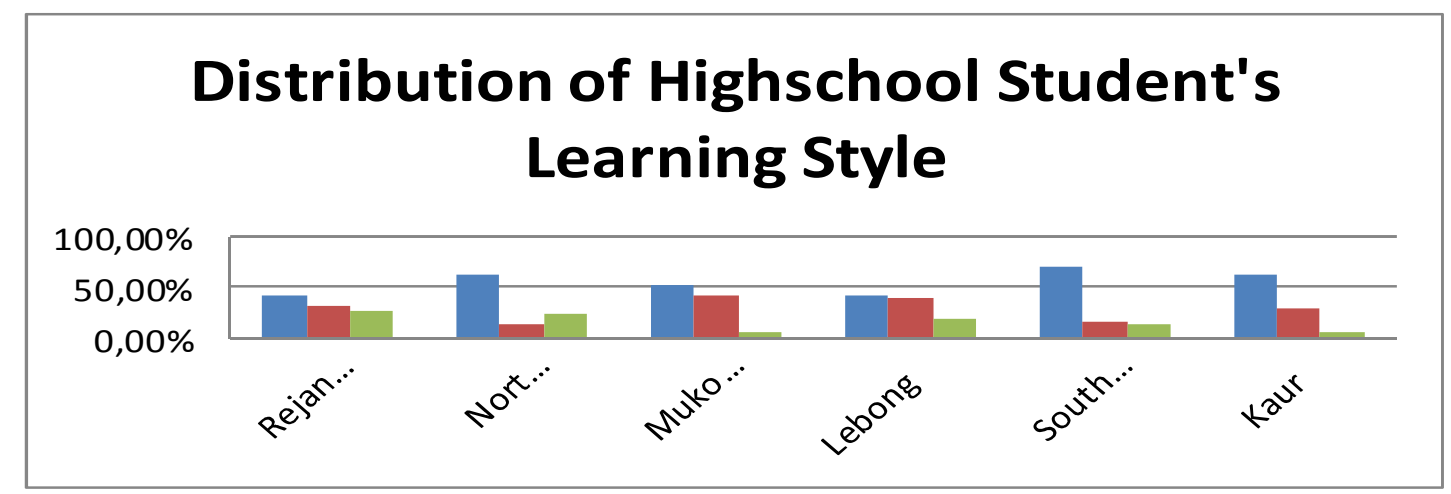

Figure 3: The Distribution of Senior High-school's Learning Style

As can be seen in the above figure, the distribution of the students' learning style among the three learning styles (visual, auditory and kinaesthetic) in each regency is rather similar in which visual learners are the most dominant one and kinaesthetic learners are the least dominant and only in North Bengkulu regency kinaesthetic learners are more dominant than auditory learners.

The second result is that that student respondents from all three different learning styles (visual, auditory and kinaesthetic) state that these 
English learning materials have several strengths or advantages; these are 1), they give suitable learning activities which match their learning style; 2), these materials with pictures and texts for reading and to listening can improve their imagination in using English either in speaking or writing; 3), they are already well designed following the tourism places in Bengkulu Province from the most popular to the least popular one; 4), they provide the students with new information about tourism places in Bengkulu which they didn't know before and wanted to know them; 5), the respondents report that in general the textbook and the $\mathrm{CD}$ or VCD could better motivate students in learning English because the book and CD or VCD introduce students to tourism objects in Bengkulu Province who may not know them all yet and this can help explain the tourism places to international visitors; and 6), the information in the English learning materials is also necessary for ordinary people who live in Bengkulu in order to be able to tell the people from other provinces about important and attractive tourism places in Bengkulu Province for the benefit of Bengkulu economy development.

However, according to the students, there are also several weaknesses of these English supplementary learning materials; these are 1) the English language used in the materials is very difficult to understand; there are many new vocabulary in the texts and there are too many assignments; 2) there are still many tourism places which are not introduced in the textbooks or CD/VCD such as 'White Water', 'Lake Picung', and so on; and 3) the pictures in the books are too few and the students suggest these English learning materials should give more pictures to help them understand the texts and to make the texts more attractive to read.

The first question in this research is on the distribution of Bengkulu province senior high-school students in terms of their learning styles. The results show that the majority of Bengkulu high-school students are categorized as visual learners. The finding of this study is contradictory to the one found by Rido (2008) in which he found from his Indonesian postgraduate student respondents that the most dominant learning style was kinaesthetic or tactile and followed by auditory and then the least dominant one was visual. 


\section{EduLite}

Journal of English Education, Literature, and Culture

Rido also investigated the learning style of post-graduate students from Iran and found that the most dominant learning style was visual which was followed by auditory and then by kinaesthetic or tactile style. These different findings may be because as Mishan (2005), when referring to the results of earlier learning style studies, such as from Little and Singleton (1990) and Tomlinson (1998), states that learner's learning styles are not always unchangeable but can be developed and extended following student's selflanguage and learning development. In other words, student's learning styles are not stable but labile and potentially influenced by student's language competence development and their self-confidence.

The second question in this research is about the perception of Bengkulu province senior high-school students on local oriented and learning style-based English learning materials. The research findings show that the majority of the student samples found that the learning style-based and local oriented English supplementary learning materials used in this experimental research interesting and suitable but rather difficult.

Tomlinson (2008:3) criticizes that the majority of commercially published English teaching and learning materials have failed to help students of English as a second or foreign language to acquire the language because they deal with the 'linguistic items rather than on the provision of opportunities for acquisition and development.' According to him, these teaching and learning materials have even contributed to the unsuccessfulness of the students to master English.

Therefore, as Tomlinson further claims '... English teaching and learning] materials for learners at all levels must provide exposure to authentic use of English through spoken and written texts with the potential to engage the learners cognitively and affectively (p:4)' In other words, English teaching and learning materials should give students sufficient chances and time to use the language in real and meaningful communication on the topics that are already familiar and interesting to them rather than spending time to explain how the language works in terms of its rules and regulation.

This is what these English learning materials are aimed at, that is providing the students with plenty of chances and time to use English for 
authentic purposes in reading, listening, watching, writing, and talking between the students inside or outside the classroom. The topics discussed in the learning materials are the ones familiar to and interesting for the students so that they will be motivated to read and discuss them in English with their class mates.

By involving more students' senses and body movement in learning English such as hearing, seeing, touching, and so on their learning processes will be more effective. This is because as Felder and Henriques (1995) say, “... students retain $10 \%$ of what they read, $26 \%$ of what they hear, $30 \%$ of what they see, $50 \%$ of what they see and hear, $70 \%$ of what they say, and $90 \%$ of what they say as they do something (p:21)." In other words, what should be done to make teaching and learning English as a foreign language effective is to vary teaching and learning materials and teacher's teaching techniques if grouping students according to their preferred learning styles is impossible.

\section{CONCLUSION}

From the research results as pointed out above, several conclusions can be drawn as the followings: 1) The majority of senior high-school students in Bengkulu province have visual learning style; 2) The learning style-based and local oriented English supplementary learning materials used in this experimental research are found interesting and suitable but rather difficult by the senior high school students in Bengkulu province selected as samples in this research; 3) the English learning materials with picture stories and visual and audio learning media help students learn English better; 4) the learning materials have been designed very well according to the students by using texts and pictures already familiar with them; 5) the strengths of the English learning materials is that it provides new information on tourism places in Bengkulu Province which the students like and want to know more about, and 6) the learning materials (the text books and VCD/CD) could improve their motivation to learn English.

The respondents suggest the following things should be done to improve the quality and attractiveness of the supplementary English learning materials: 1) the cover of the textbook should be made more interesting and 
artistic; 2) the voice description in the VCD should match the picture arrangement in the textbook; 3) there should be subtitle following the pictures in the VCD and CD so that the students can read them in order to better understand them; and 4) These learning materials should be used at all senior high-schools in Bengkulu province especially for supplementary English learning materials.

\section{REFERENCES}

Banner, G. and Rainer, S. (2000). Learning language and learning style: Principles, process and practice', Language learning journal, No. 21, pp: 73-44.

Bond, V. (2002). Successful language learners, downloaded from Internet with the address of www.iteslj.

Borg, W.R. and Gall, M.D. (1989). Educational research. New York: Longman.

Bialystok, E. (1981). The role of conscious strategies in second language proficiency' Modern language journal, 65/2, pp: 24-35.

Bialystok, E. (1978). A theoretical model of second language learning. Language learning. 28/1. pp: 69-83.

Cahyono, B.Y. and Widiati, U. (Eds.) (2004) English language teaching and learning in Indonesia. Malang: State University of Malang.

Dinas Pendidikan Nasional Propinsi Bengkulu (2005). Profil pendidikan propinsi Bengkulu. Bengkulu: Dinas Diknas.

Dinas Pendidikan Nasional Propinsi Bengkulu (2004). Hasil tes kompetensi guru mata pelajaran SMP/MTs. Jakarta: Departemen Pendidikan Nasional, Dikdasmen Direktorat Pendidikan Lanjutan Pertama.

Dickinson, L. (1987). Self-instruction in language learning. Cambridge: Cambridge University Press.

Dick, W., \& Carey, L. (1990). The systematic design of instruction (3rdEd) Glenview. Illinois: Scott, Foreman and Company.

Elley, W. B. and Mangubhai, F. (1983). The impact of reading on second language learning. Reading research quarterly, 19/1: 53-67.

Felder, R.M. and Henriques, E.R. (1995). Learning and teaching styles in foreign and second language education. Foreign language annals, Vol. 28, No. 1, pp: 21-31. 
Arsyad, Students' Learning Style: A Case Study of Senior High Schools in Bengkulu

Hafiz, M. and Tudor, I. (1989). Extensive reading and development of language skills. ELT journal, 43/1, pp: 4-13.

Jazadi, I. (2004). ILT in Indonesia in the context of English as a global language. in Cahyono, B.Y. and Widiati, U. pp: 1-15.

LPMP Bengkulu (2007). Laporan hasil Ujian Nasional (UN) SMP dan SMA Propinsi Bengkulu, an unpublished material.

Mantiri, O. (2004) Problematic issues of ELT in Indonesia. in Cahyono and Widiati (eds.). pp: 18-29.

Mishan, F. (2005). Designing authenticity in to language learning materials. Portland Oregon: Intellect Books.

Nunan, D. (1991). Language teaching methodology. New York: Prentice Hall.

Oxford, R. L. (2003). Language learning styles and strategies: An overview. Learning styles and strategies, GALA pp: 1-23.

Patel, M. F. and Jain, P.M. (2008). English language teaching: methods, tools and technique, Jaipur: Sunrise Publishers.

Priyono (2004). Logical problems of teaching English as a foreign language in Indonesia. in Cahyono dan Widiati (eds.) pp: 17-28.

Rido, A. (2008). Learning style: An attempt to negotiate with Pluri-globalised cultural classroom situation (Indonesia, Iranian and Libyan's Prospective, a paper presented in ASIA TEFL International Conference on 1-3 August, 2008 in Bali Indonesia.

Safnil (1991). Outside the classroom learning activities preferred by successful English learners at Bengkulu University, an unpublished research report.

Tomlinson, B. (ed.) (2008). English language learning materials: A critical review. London: Continuum International Publishing Group.

UPT Bahasa Inggris (2006). Laporan hasil pelaksanaan tes TOEFL calon wisudawan Universitas Bengkulu. an unpublished report form UPT Bahasa Inggris Universitas Bengkulu.

Wenden, A. (1998). Learner strategies for learner autonomy. Great Britain: Prentice Hall. 